\title{
A large multi-centric study in the United States assessing self-cure rates in dairy cows during the dry period from mastitis due to Staphylococcus aureus
}

\author{
L Reeve-Johnson ${ }^{1 *}$ and SC Nickerson ${ }^{2}$ \\ ${ }^{1}$ Department of Veterinary Pharmacology, School of Veterinary Sciences, University of Queensland, QLD,4072, Australia \\ ${ }^{2}$ Edgar L. Rhodes Center for Animal and Dairy Science, University of Georgia, Athens 30602, Georgia, USA
}

\begin{abstract}
In a multicentric study, several factors were demonstrated to be linked to the ability of dairy cows to spontaneously or self cure (without dry cow therapy) over the nonlactating period from natural intramammary infections (IMI) caused by Staphylococcus aureus. Self-cure was found to be twice as likely in primiparous cows compared to multiparous cows. It was also found that primiparous cows with quarter cell counts $<1.25 \times 10^{6} / \mathrm{ml}$ had a self cure probability four times greater than either primiparous or multiparous cows with higher cell counts. No cows with 3 or 4 quarters infected were found to self-cure, while $7-8 \%$ of those with 1 or 2 quarters infected were found to self-cure. Short dry periods were associated with a higher probability of self-cure. Farms which segregated cows into sub-herds of $S$. aureus infected and non-infected cows reduced the probability of a self-cure in the infected groups five-fold for multiparous cows compared to those where cows remained in the herd. A predictive model developed for the likelihood of self cure based upon the quarter somatic cell count (QSCC) showed that the probability of self-cure decreased by approximately $2 \%$ per additional 100,000 cells $/ \mathrm{ml}$ from $100,000-500,000$ cells $/ \mathrm{ml}$ then a further $2 \%$ per 500,000 cells up to 1,500000 cells $/ \mathrm{ml}$. This tool could be useful as an aid in the prioritization of treatment or culling decisions.
\end{abstract}

\begin{abstract}
Abbreviations: QSCC: Quarter SCC, IMI: Intramammary infection
\section{Introduction}

Bovine mastitis is one of the most costly diseases of foodproducing animals in the US and Europe. Cow mortality, impaired production, increased treatment costs, decreased milk quality, and potential human health concerns are among the consequences of infection of the bovine mammary gland. Staphylococcus aureus is one of the most difficult organisms to treat, especially during lactation, and there are no intramammary infusion products currently available that effectively eliminate $S$. aureus IMI from herds. The end of lactation is a common time to administer antimicrobial therapy to $S$. aureusinfected cows because antibiotics are able to remain in the udder at higher concentrations for prolonged periods to effect a cure $[1,2]$. Schukken et al. [3] showed that 3 percent of all animals are infected with S. aureus, and Tenhagen et al. [4] found that $S$. aureus represents 10 to 12 percent of all clinical mastitis infections. Cows infected with $S$. aureus do not necessarily have elevated SCC. During 1978-1980, nearly 27,000 milk samples from 28 herds were aseptically collected. Culture results showed 10 percent of cows were infected with S. aureus [5].
\end{abstract}

Decrease in milk yield has been shown to be the largest cost associated with mastitis, however there is discrepancy within the literature as to the precise figure [6-15]. The National Mastitis Council estimates yield loss at 70 percent of total mastitis costs [16]. Milk loss due to mastitis results in an average milk yield loss per cow of $0-9 \%$ in the first lactation and approximately $0-11 \%$ in the second lactations and beyond [17]. The size of this loss is clearly huge. Holland et al. [18] provide a useful synthesis of the economic importance of these losses and present a model to calculate this using contemporary figures.
For successful mastitis control, clearly it is important to identify $S$. aureus-infected cows and quickly treat or cull such that spread S. aureus is reduced. However, principally due to the expense of conducting large negative control studies, there is little conclusive literature assessing the extent to which cows self-cure during the dry period.

The aim of this study was to examine the self-cure rate in nontreated $S$. aureus-infected cows to determine the baseline against which product efficacy should be assessed, and to identify factors that affect the ability of cows to spontaneously cure an infection without intramammary treatment.

\section{Materials and methods}

\section{Study design}

A multicentric study was initiated involving 10 herds in 5 disparate geographic locations in the US. All study sites conformed strictly to a uniform predetermined protocol. Bacteriology was conducted using the same methodology in a single laboratory for samples collected from the herds. All sample collection phases of the study were conducted in accordance with Good Clinical Practice for Veterinary Studies standards, and the laboratory phase was conducted according to Good Laboratory Practice standards. An independent Quality Assurance

Correspondence to: L. Reeve-Johnson, Department of Veterinary Pharmacology, School of Veterinary Sciences, University of Queensland, QLD 4072, Australia, E-mail: 1loyd@goydpark.com

Key words: dry period, mastitis, self-cure, Staphylococcus aureus

Received: March 18, 2017; Accepted: April 14, 2017; Published: April 17, 2017 

aureus

inspection was used to validate these practices prior to and during the trial.

\section{Sample collection}

Herds with a history of $S$. aureus infection were screened based on past bacteriological analyses and elevated bulk somatic cell count (SCC). If there was evidence of a likely $S$. aureus problem, composite samples for milk from all functioning quarters from all cows in the herd were taken and if the herd prevalence of $S$. aureus was $\geq 15 \%$ of cows, then the herd was selected. Milk samples from all quarters of all cows identified as infected in these herds were cultured, and cows were enrolled based upon bacteriological evidence of $S$. aureus infection. The Fossomatic cell counter (A/N Foss Electric, Hillerod, Denmark) was calibrated up to $20 \times 10^{6}$ cells $/ \mathrm{ml}$, and counts above this were recorded as $>20 \times 10^{6}$ cells $/ \mathrm{ml}$ rather than a value being ascribed from outside the calibrated range. Dairy cows in their first to fifth lactation, and ready for drying off were enrolled in the study. Recommended procedures (NMC) were followed for the aseptic collection and preparation of all milk samples taken at the study sites. Fore stripping of each teat was practiced prior to sampling to reduce the risk of sample contamination and teat ends were cleaned with an iodophore teat dip and dried, an alcohol swab was then applied before sampling.

\section{Sample analysis and handling}

Samples were frozen in their collection vials prior to dispatch to the laboratory for quarter somatic cell count (QSCC) and bacteriology. Samples were courier transported on ice and processed within approximately 24 hours of being taken. Blood agar with $0.1 \%$ esculin was used for the culture of bacteria from the milk samples and aliquots of $0.1 \mathrm{ml}$ inoculum were swirled plated across the surface. Plates were incubated for $24-48$ hours at $35-37^{\circ} \mathrm{C}$ being checked periodically during this period for Staphylococcal colonies. Staphylococcus aureus colonies are typically large (2-5 $\mathrm{mm}$ at 24 hours, $3-8 \mathrm{~mm}$ at 48 hours) smooth, entire, pigmented colonies on blood agar and are typically accompanied by zones of incomplete and complete haemolysis with distinct outer edges. A positive reaction in the coagulase tube test was used as additional confirmation. All cows had at least 3 functional quarters, were confirmed pregnant by palpation per rectum, and were in good body condition. Cows were excluded from the study if they received antibiotic therapy (except topical or foot bath treatments) from the day of the first milk sample collection ( $d-14$ to $d-7$ relative to dry-off) until the end of the trial.

Bacterial cultures of quarter milk samples collected between $\mathrm{d}-14$ and $\mathrm{d}-7$ before drying off and on the day of drying off were compared with bacterial cultures from each quarter of each cow collected on 5 to 8 days in milk (DIM), 11 to 17 DIM, and 19 to 25 DIM; QSCC were determined from samples collected between $\mathrm{d}-14$ and $\mathrm{d}-7$ before dryoff and at 5-8 DIM. To qualify as an infected quarter, one or both of the predry-off samples needed to culture positive for $S$. aureus. Infected quarters were considered cured only if all of the postcalving samples cultured negative for the infecting bacterium.

\section{Statistics and analysis}

A generalized linear mixed model was used to analyze the cow and quarter self-cure rate data. The analysis used a logit link function, a binomial error likelihood, and restricted pseudo likelihood approach [19]. Factors included in the model were investigator, herd within investigator, and parity. Somatic cell count and number of quarters infected were considered as cow-level covariates. Investigator and herd within investigator were random factors; parity, SCC coefficient, and number of quarters infected were fixed factors.

Forty-five herds were screened for S. aureus infection and 10 herds were included in this study based upon $\geq 15 \%$ of cows being identified upon initial screening as being infected with $S$. aureus using composite milk samples, 2 from each of 5 disparate geographical locations. The final study population of $S$. aureus-infected cows that met the criteria from which a complete set of bacteriological samples from all functional quarters at each sample time was obtained, formed a study population of 341 cows. The herd identity, location, herd size, and breed of cattle are provided in Table 1. Herds 9 and 11 used tie-stall barns for milking and winter housing; all others had 'free-stalls' and milked in herringbone parlors.

To test the hypothesis that a proportion of the self-cure failures may be due to new infections subsequent to initial success at self-cure, 15 pre- and post- dry period isolates were selected from quarters which had been classified as not having self-cured. These were then analyzed using Random Amplified Polymorphic DNA analysis. In this process, genomic DNA is isolated and arbitrary primers or approximately 10 base pairs in length are added. They are then run through a Polymerase Chain Reaction (PCR) which amplifies these sequences. The PCR products generated are then fractionated by size using gel electrophoresis to give characteristic banding patterns (or a genetic fingerprint) which are used to distinguish the strains.

\section{Results}

Table 2 shows the number of cows with 1, 2, 3, or 4 quarters infected for each site. At all sites except 1 and 11, most cows had only one quarter infected (median=69\%). In herd $11,80 \%$ had 2 or more

Table 1. Herd identifier, location, size, breed type, and number of $S$. aureus-infected cows.

\begin{tabular}{|l|l|c|c|c|c|}
\hline Herd & Location & Herd size & Type & $\begin{array}{c}\text { Presence of separate } \\
\text { S. aureus 'sub-herd' }\end{array}$ & $\begin{array}{c}\text { No. of S. aureus } \\
\text { infected cows }\end{array}$ \\
\hline 1 & Louisiana & 100 & Jersey & No & 50 \\
\hline 2 & Louisiana & 300 & Holstein & No & 16 \\
\hline 3 & California & 2000 & Holstein & Yes & 97 \\
\hline 5 & Colorado & 1500 & Holstein & Yes & 10 \\
\hline 6 & Colorado & 300 & Holstein & No & 0 \\
\hline 7 & California & 1700 & Holstein & Yes & 81 \\
\hline 9 & Michigan & 120 & Holstein & No & 21 \\
\hline 11 & New York & 55 & Holstein & No & 30 \\
\hline 12 & New York & 1500 & Holstein & Yes & 9 \\
\hline 13 & Michigan & 130 & Holstein & No & 27 \\
\hline
\end{tabular}

Table 2. Number (percentage) of cows with 1, 2, 3, or 4 quarters infected for each site.

\begin{tabular}{|c|c|c|c|c|c|c|}
\hline \multirow[t]{2}{*}{ Herd } & \multicolumn{4}{|c|}{ No. quarters infected } & \multirow{2}{*}{$\begin{array}{l}\text { Number of } \\
\text { cows in herd }\end{array}$} & \multirow{2}{*}{$\begin{array}{c}\text { Number of infected } \\
\text { S.aureus quarters in } \\
\text { herd }\end{array}$} \\
\hline & 1 & 2 & 3 & 4 & & \\
\hline 1 & $18(36)$ & $20(40)$ & $7(14)$ & $5(10)$ & 50 & 99 \\
\hline 2 & $11(69)$ & $4(25)$ & 0 & $1(6)$ & 16 & 23 \\
\hline 3 & $54(55)$ & $36(37)$ & $3(3)$ & $4(3)$ & 97 & 151 \\
\hline 5 & $9(90)$ & $1(10)$ & 0 & 0 & 10 & 11 \\
\hline 7 & $59(72)$ & $11(14)$ & $9(11)$ & $2(2)$ & 81 & 116 \\
\hline 9 & $12(57)$ & $5(24)$ & 4 (19) & 0 & 21 & 34 \\
\hline 11 & $6(20)$ & $6(20)$ & $12(40)$ & $6(20)$ & 30 & 78 \\
\hline 12 & $8(89)$ & $1(11)$ & 0 & 0 & 9 & 10 \\
\hline 13 & $21(77)$ & $6(22)$ & 0 & 0 & 27 & 33 \\
\hline $\begin{array}{l}\text { Total no. } \\
\text { cows } \\
\text { infected }\end{array}$ & $198(58)$ & $90(26)$ & $35(10)$ & $18(5)$ & 341 & 555 \\
\hline
\end{tabular}



aureus

quarters infected including $40 \%$ with 3 quarters infected. In herd 1 , $64 \%$ of cows had 2 or more quarters infected including $40 \%$ with 2 quarters infected. Two other sites had over $10 \%$ of cows with more than 2 quarters infected (herds 7 and 9), and all sites had between 10 and $40 \%$ of cows with 2 quarters infected.

\section{Self-cure by parity}

The bacteriological self-cure rate from $S$. aureus infection during the nonlactating period was established at each site. The self-cure in primiparous cows was $13.1 \%$, which was over 2 -fold greater than the self-cure of multiparous cows (5.2\%). There were site differences in self-cure rates, and the range was 0 to $20 \%$.

The mean cure rates at each sample point across the study can be calculated either by averaging the proportion of cures per site (weighted mean) or by dividing the total number of cows which self cured in the entire study by the total number of infected cows enrolled (unweighted mean). These 2 values are illustrated in Table 3. The latter method is more influenced by herds with larger numbers of infected cows and could lead to a bias in the overall mean cure rate due to a site effect in one large herd. In this study, the cure rates were lowest at the 2 largest sites, thus the unweighted mean of the cure rate is lower than the weighted mean. With a large number of sites of a similar size, the unweighted approach might be favored, whereas with a small number of herds or where there is a large difference in herd size, the weighted approach may be more suitable. Both methods are presented; although, overall the trends are similar.

At each sample time, the self-cure rates at the 2 largest sites (California) were significantly lower $(P \leq 0.05)$ than the other sites, with the exception of primiparous cows for which the unweighted mean self-cure rate was $14.3 \%$ at 2 California sites and $8.3 \%$ at the others $(P=0.1)$. Because approximately half of the cows originated from these 2 sites, it was decided to compare the data of the 2 California sites with the combined data from the other sites while also examining the difference in self-cure rates between primiparous and multiparous cows (Figure 1). None of the other sites had enough cows to be used as a stand-alone comparison. The difference in self-cure rate at each of the bacteriological sampling times is illustrated in Figure 2. When the site effects were considered, the self-cure rates at the 2 largest (California)

Table 3. Unweighted and weighted means of cow cure rates (percentage).

\begin{tabular}{|l|c|c|c|}
\hline & DIM 5-8 & DIM 11-17 & DIM 19-25 \\
\hline Weighted mean & 13.4 & 7.9 & 7.9 \\
\hline Unweighted mean & 7.8 & 6.0 & 6.0 \\
\hline
\end{tabular}

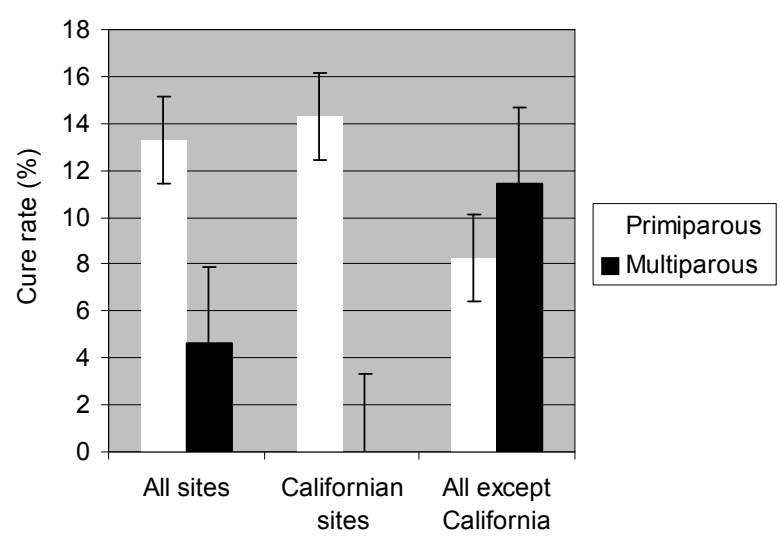

Figure 1. Weighted mean cure rate for 341 S. aureus-infected cows.

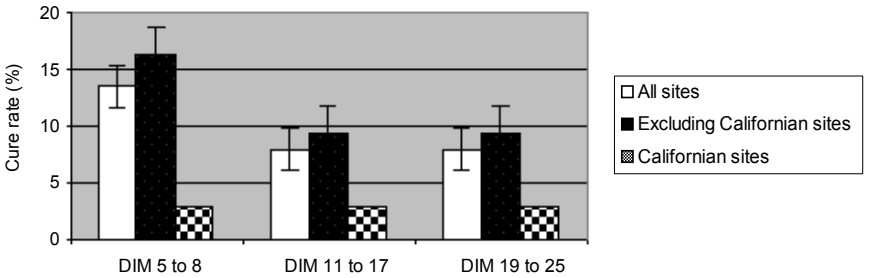

Figure 2. Percentage cure for all cows infected with S. aureus at drying off for each of 3 postcalving sampling times.

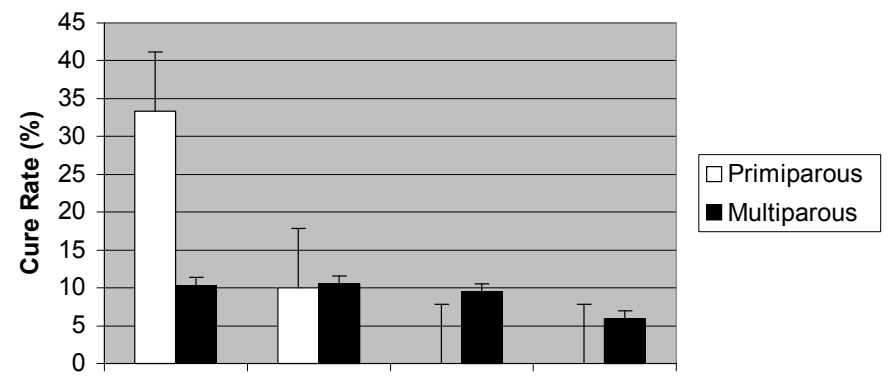

1st quartile 2 nd quartile 3 rd quartile 4 th quartile

Figure 3. Quarter cure rate sorted by parity and quartile of QSCC for infected quarters.

sites were significantly $(P \leq 0.05)$ lower than those at the other sites.

\section{Quarter cure by QSCC before dry-off}

The quartiles of the infected QSCC were determined to be: $1^{\text {st }}$ quartile 0 to $1140 \times 10^{3} / \mathrm{mL} ; 2^{\text {nd }}$ quartile $1141 \times 10^{3}$ to $3187 \times 10^{3} / \mathrm{mL}$, $3^{\text {rd }}$ quartile $3188 \times 10^{3}$ to $8514 \times 10^{3} / \mathrm{mL}$, and $4^{\text {th }}$ quartile $>8514 \times 10^{3} /$ $\mathrm{mL}$. The cure rate by parity and QSCC is illustrated in Figure 3. High QSCC quarters (3rd and especially 4th quartile) whether multiparous or primiparous, were less likely to self-cure. In all cases, the quarters of cows from the quartile with the highest SCC, whether primiparous or multiparous, had a significantly lower $(P \leq 0.05)$ cure rate than quarters from cows in the first or second quartile the difference was not significant to those in the 3 rd quartile.

\section{Cow cure by QSCC before dry-off}

If instead, cows were adopted as the experimental unit and were sorted according to combined QSCC results for all functional quarters, the quartiles were: 1st quartile: 0 to $1255 \times 10^{3} / \mathrm{mL}, 2^{\text {nd }}$ quartile: $1256 \times 10^{3}$ to $3039 \times 10^{3} / \mathrm{mL}, 3^{\text {rd }}$ quartile: $3040 \times 10^{3}$ to $8543 \times 10^{3} / \mathrm{mL}$, and $4^{\text {th }}$ quartile: $>8543 \times 10^{3} / \mathrm{mL}$. The cow cure rate (the elimination of infection in all quarters) by parity and SCC is illustrated in Figure 4. Overall, it was seen that for multiparous cows (and primiparous cows above the first quartile), cure rate was very low $(<8 \%)$. Primiparous cows with SCC $<1.25 \times 10^{6}$ had self-cure rate of $37.5 \%$.

\section{Cow cure by presence or absence of segregation of $S$. aureus -infected cows}

When those herds where cows were segregated into sub-herds containing all cows in which $S$. aureus IMI had been already detected (Herds $3,4,7,12$ ) were compared with those where this management tool was not used, it was found that segregation of cows was associated with a decreased self-cure rate in multiparous cows from 10 to $2 \%(P$ $\leq 0.05$ ) and from 11 to $10 \%$ (non-significant, $P>0.2$ ) in primiparous cows.

Self-cure rate decreased from 9 to $2 \%(P \leq 0.05)$ as herd size 

aureus

increased in multiparous cows, yet tended to increase in primiparous cows (non-significant); this effect is illustrated in Figure 5.

\section{Cow cure sorted by the median number of $S$. aureus -infected cows in the herd}

The lower the number of $S$. aureus-infected cows in the herd, the better the cure rate appeared in both primiparous and multiparous cows. This is illustrated in Figure 6, in which the herd is categorized according to whether there were more than or less than the median number of $S$. aureus-infected cows across all sites present in that herd. The difference was significant for multiparous cows at the $95 \%$ confidence interval $(P=0.05)$ but only at the $90 \%$ confidence interval for primiparous cows $(P=0.1)$.

\section{Cow cure by length of the dry period}

There was no self-cure in either primiparous or multiparous cows within the longest quartile of dry period (77 to $90 \mathrm{~d}$ ). Dry periods of 35 to $48 \mathrm{~d}$ (the lowest quartile) were associated with better cure rates (23\%). This difference is significant using a $95 \%$ confidence interval. There were not enough primiparous cows in the upper or bottom quartiles of the dry period ( 3 in each) to compare results with multiparous cows.

\section{Cow cure by number of quarters initially infected}

If number of quarters infected per udder was greater than 2 , the selfcure rate decreased to 0 . Seven percent of cows with 1 quarter infected self cured, $8 \%$ of cows with 2 quarters self cured, and none with 3 or 4 quarters self-cured. There was no statistical difference between cows able to fully eliminate infection from one or two quarters $(P<0.05)$, yet the difference is significant if the self-cure in all infected quarters of those with one or two quarters infected is compared with those with three of four quarters infected $(P<0.05)$.

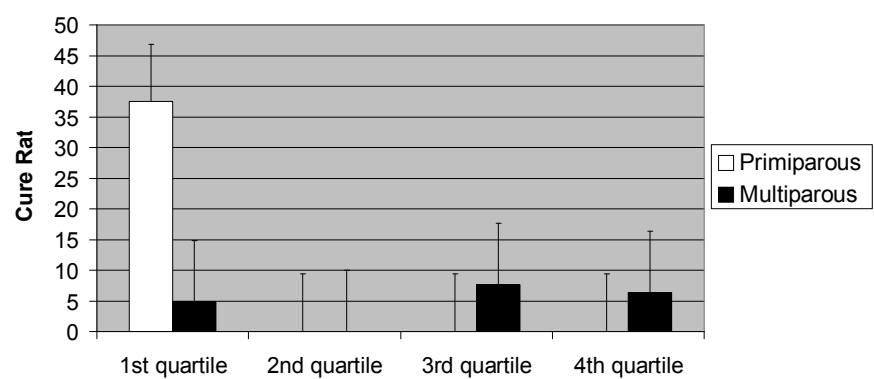

Figure 4. Overall cow cure rate, sorted by parity and quartile of the combined QSCC data for each cow.

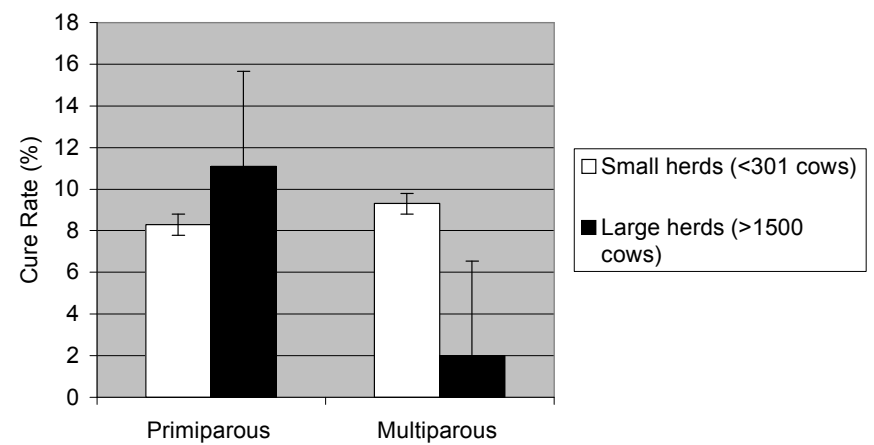

Figure 5. Cow cure rate from S. aureus infections of the mammary gland and parity according to herd size.

\section{Cow cure sorted by other factors}

There were no association between month of calving, month of drying off or quarter location within udder and either quarter or cow self-cure.

\section{RAPD-PCR analysis of $S$. aureus strains}

Random Amplified Polymorphic DNA (RAPD) analysis in combination with Polymerase Chain Reaction (PCR) and Gel Electrophoresis confirmed that bacteriology under-estimates the selfcure rate. New infections were demonstrated to have been caused by a different strain of $S$ aureus in five out of the 15 pairs of samples analyzed [30].

\section{Statistical interpretation of results}

The bacteriological and QSCC data were recorded for each quarter for each cow during the study. A generalized linear mixed model was used to analyze the cow and quarter cure data, which included a variance component estimate, which confirmed that there was no cure rate interaction with the investigator. Table 4 shows coefficients of fitting fixed effects on a log scale, the estimated $\log _{10}$ (predry-off SCC) was used to generate the cure rate data for various SCC as given in Table 5. The coefficient of $\log _{10}$ (pretreatment SCC) is -0.7692 , thus as $\exp (-0.7692)$ is 0.46 , a ten-fold increase in SCC approximately halves the odds in favor of a cure.

\section{Discussion}

There was a 2 months delay between the initial identification of

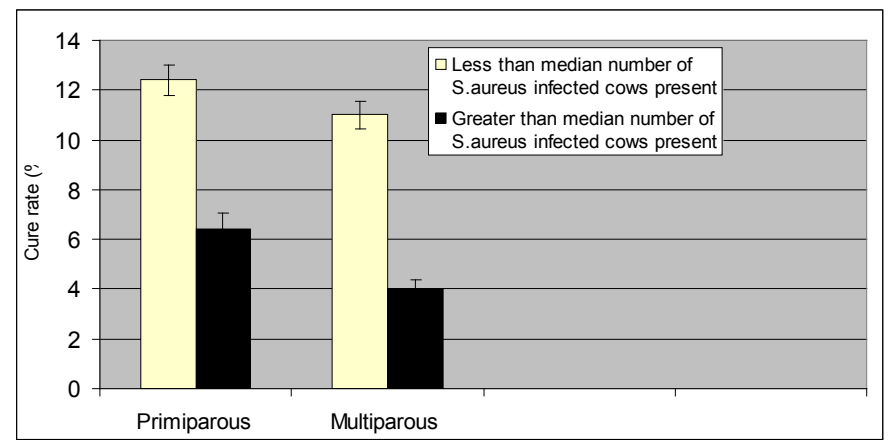

Figure 6. Cow cure rate by parity and treatment using the median number of $S$. aureus infected cows as a predictor of cure rate.

Table 4. Coefficients of fitted fixed effects on logit scale.

\begin{tabular}{|c|c|c|c|}
\hline Effect & Level & Estimate & Standard error \\
\hline Intercept & - & 2.5961 & 1.4585 \\
\hline Parity & Multiparous & -1.3753 & 0.4707 \\
\hline & Primiparous & 0 & - \\
\hline $\log _{10}$ (pre-drying-off SCC) & - & -.7692 & 0.4080 \\
\hline
\end{tabular}

Table 5. LS-Means of cure rates at various average predrying off QSCC.

\begin{tabular}{|c|l|l|}
\hline $\mathrm{SCC}=100,000$ & Self-cure & $22 \%$ \\
\hline $\mathrm{SCC}=200,000$ & Self-cure & $19 \%$ \\
\hline $\mathrm{SCC}=300,000$ & Self-cure & $17 \%$ \\
\hline $\mathrm{SCC}=400,000$ & Self-cure & $15 \%$ \\
\hline $\mathrm{SCC}=500,000$ & Self-cure & $14 \%$ \\
\hline $\mathrm{SCC}=750,000$ & Self-cure & $13 \%$ \\
\hline $\mathrm{SCC}=1,000,000$ & Self-cure & $12 \%$ \\
\hline $\mathrm{SCC}=1,500,000$ & Self-cure & $10 \%$ \\
\hline $\mathrm{SCC}=2,000,000$ & Self-cure & $10 \%$ \\
\hline
\end{tabular}



aureus

herds with $\geq 15 \%$ prevalence of $S$. aureus infection and the start of the study. It was noted that most herds by this time had $<15 \%$ S. aureus infection as evidenced by the samples taken at this time. Although the results of the initial screening of herds was kept confidential from herd owners, it is thought that the sampling process, issuing the contract, inclusion of the herds in the study and continued interest in the herds in general raised awareness of a potential S. aureus problem and that stricter management practices and culling policies were used in the interim in these commercial herds. The definition of the quarter or the cow as the determinative statistical unit affects the trial design and the number of cows that should be included. In terms of bacteriology, the quarter is the relevant unit, and it is by bacteriological cure that efficacy would be assessed for IMI products in both the Committee for Veterinary Medicinal Products in Europe [20] and CVM/FDA guidelines in the USA [21]. Product efficacy claims for both ethical and cost liability reasons are usually based upon the use of positive control product comparisons, assessing bioequivalence with products that are already licensed. This approach does not account for the natural rate of self-cure in cows and therefore assumes that the chosen licensed comparator product has a significant benefit above the natural selfcure rate. Quarter cure rates within a cow have been shown not to be independent [22]. Using the cow as the statistical unit takes account of confounding factors specific to the cow that influence the capability of a cow to cure infection either with or without treatment.

In this study, the self-cure rate of S. aureus IMI of primiparous cows was found to be $13.1 \%$, and that of multiparous cows was $5.2 \%$. There was a decline in the self-cure rate of $5.5 \%$ between the first and the third sample using the weighted approach or a decline of $1.8 \%$ using the unweighted approach (Table 3). The decline may be due to intermittent shedding of the organism or insufficiently sensitive bacteriological examination; alternatively, it might be due to reinfection of the same quarter in the cow with a new organism either of the same or a different strain [23].

Site differences were observed, and these were attributed to the presence or absence of segregation of $S$. aureus-infected cows from the rest of the herd, herd size, and parity. The data were analysed for risk factors associated with a decrease in cow and quarter rates. Significant risk factors were found to be high QSCC, increasing numbers of quarters infected, segregation of infected cows, and increasing parity, all of which decreased cure rates.

A statistical model was constructed to predict self-cure rates, which illustrated that the chance of a successful self cure effectively halves with a 10-fold increase in QSCC. The predictive value of models such as this can help in making treatment and culling decisions.

Data gathered by Whitaker et al. [24] indicated that overall average total culling rate for dairy cows in UK was $22 \%$, of which $3.6 \%$ was for mastitis, and that clinical mastitis was recorded in $36.6 \%$ of cows each year. However, there was marked interherd variation in that the $10 \%$ of herds with the fewest cases of mastitis had an average of 8.3 cases per 100 cows, while the worst $25 \%$ had 70 cases per 100 cows. The mean bulk tank milk SCC (BTSCC) was 140,000 cells/mL, with the highest individual herd monthly SCC figure being 515,000 and the lowest $14,000 / \mathrm{mL}$. A combination of management factors as well as cow factors such as yield, parity, and genetic predisposition contribute to herd differences. This study used a statistical model that was specifically factored for investigator, herd, and geography to avoid herd factors confounding the analysis of the contributions of other variables to the cure rate.
One herd factor examined in this study was the contribution of the presence or absence of segregation of $S$. aureus-infected cows into a discrete subherd of cows. This has been recommended as a means of decreasing the spread of $S$. aureus infection as an interim method of control $[25,26]$. Although this practice limits the transmission of contagious mastitis pathogens to uninfected cows in the rest of the herd, the result is the creation of a subherd with a $100 \%$ prevalence of $S$. aureus infection. These data supported the conclusion that it is more difficult for infected cows to self-cure within $S$. aureus subherds. Presumably, this is due to reinfection from contact with infected animals.

The significantly lower self-cure rates in the 2 largest herds may be partly due to the density of infected cows within the segregated groups in these herds. These $S$. aureus-infected groups of cows were large ( 79 and 81 cows at the 2 Californian sites compared with 9 and 10 cows at the other 2 sites that used segregation) and were not housed in proportionately larger pens; thus, the mean area per infected cow was decreased, and the probability of making contact with infected cows was increased. In the 6 herds that did not segregate infected cows as a management tool, infected cows were dispersed throughout the entire herd. Additionally, in herds using segregation, many more infected cows are milked in succession, and there is a greater likelihood of infection occurring at this time even with rigorous hygiene protocols. Finally, in small herds, there is often a sole dairyman who detects mastitis and other health problems, and that individual follows up on the management of these cases. Thus, measures such as the initiation of treatment are often started more quickly and consistently than in large herds in which shifts of milkers operate a constant throughput system.

Nickerson et al. [27] illustrated superior self-cure and treatment response rates to $S$. aureus mastitis in breeding age and pregnant dairy heifers. This supports the approach in which primiparous and multiparous cow data were analyzed separately as 2 populations of cows with inherently different capacities for self -curing from intramammary infections.

The QSCC was strongly indicative of the likelihood of self cure, both for the quarter concerned and using the highest QSCC as an indicator of cure likelihood for the cow. Previous research also found that the cure rate of $S$. aureus-infected quarters diminishes as the SCC prior to drying off increases, and that there is a significantly lower cure rate in quarters with a QSCC of greater than 1 million cells $/ \mathrm{ml}$ [1]. [28] showed, in a university herd with a low BTSCC, that there was a low prevalence of major pathogens, and they speculated that the benefit for reducing IMI is low. Thus, our high SCC S. aureus problem herds made an interesting test population in a scenario in which the value of an effective product would be maximized. In their low SCC herd, these workers observed a $75 \%$ self-cure rate in nontreated cows. All cows in this study were infected with $S$. aureus and very few had low QSCC. For example, there were only 3 cows below 100,000 cells/ $\mathrm{ml}$. The predictive value of this model therefore increases at the higher QSCC. The geometric mean predrying off QSCC in S. aureus infected quarters from our data was $2,900,000 \mathrm{cells} / \mathrm{ml}$. This is higher than the mean of $1,500,000$ to $1,820,000$ cells/ml quoted by another researcher for $S$. aureus infected quarters [29].

The largest 2 herds in this study had significantly lower self-cure rates $(P \leq 0.05)$. Whitaker et al. [24] using data from a large survey of UK dairy herds did not find any relationship between herd size and mastitis rate, but a tendency for higher yielding herds to have more mastitis. In the case of the 2 larger herds they were high yielding herds 

aureus

but milk yields were not tracked for most of the other herds involved so this cannot be confirmed.

As the number of quarters infected per cow increased, there was a decrease in the cow self-cure rates. None of the cows infected in all 4 quarters managed to eliminate infection from every quarter, and there was a significant decrease in the ability to cure the fourth quarter as compared to the ability to self-cure a quarter in a cow with either no other, one other or two other quarters infected $(P \leq 0.05)$. This may be evidence of debilitating mastitis and an immunocompromised state, the increased risk of cross infection between quarters within the same cow, or increased genetic susceptibility of these animals.

There was a significantly greater chance of a self-cure in a primiparous cow versus a multiparous cow $(P \leq 0.05)$, dry period length was also a significant risk factor and there was no self cure in either primiparous nor multiparous cows within the longest dry period quartile. The self-cure rates significantly decreased $(P \leq 0.05)$ in both primiparous and multiparous cows as the number of quarters infected increased or the pre-drying off QSCC increased.

In this study, the predetermined failure criterion for evidence of self-cure was a single positive bacteriological sample at any of the three post-calving milk sample periods. There was no way of determining from bacteriology if the organism isolated in any of the post-calving samples was the same as the initial infecting organism. A proportion of the post-treatment isolates were shown to be new infections of a cured quarter with a different strain of $S$. aureus. Random Amplified Polymorphic DNA (RAPD) analysis in combination with Polymerase Chain Reaction (PCR) and Gel Electrophoresis was used to detect strain differences between pre-and post-calving samples from quarters where there was no apparent self-cure [30]. This technique confirmed that bacteriology under-estimates the self-cure rate. New infections were demonstrated to have been caused by a different strain of $S$. aureus in five out of the 15 pairs of samples analysed. The implication is that potentially one third of the apparent treatment failures are actually accounted for by new infections establishing in a self-cured quarter. Clearly this will be heavily influenced by management practices and the opportunities for transfer for infection between quarters both within and between cows. This proportion would be increased if it were possible to additionally identify new infections caused by the original strain re-establishing in the quarter after an initial cure. Rivas et al. [30] in their study on a sample population of 22 commercial dairy herds in New York State, using an automated ribotyping technique, set out to establish a reference database on $S$. aureus strains. Out of 50 isolates, from 12 of the herds, they identified 18 ribotypes. They found that $S$. aureus ribotypes were broadly distributed geographically with one of every four ribotypes disseminated over a 150-mile distance and explaining $36 \%$ of all isolates. They found a range of 1-4 ribotypes in any one herd and assessment of in vitro susceptibility of antibiogram profiles revealed three of five $S$. aureus ribotypes (including four or more isolates) to be marginally or substantially associated with antibiogram profiles. On average, there were less than four strains of $S$. aureus present in a single herd. Thus approximately $25 \%$ of reinfections (or the relative prevalence of the initial infecting strain) may be due to the original strain: even RAPD techniques cannot distinguish this from a persistent infection.

Few studies have been done on non-treated S. aureus infected cows, the most conclusive results are from trials of antimicrobial therapies. Sol et al. [1] analyzed data from 5 dry cow antibiotic therapy trials, which included $406 \mathrm{~S}$. aureus infected quarters from 283 cows on 73 farms. They identified a number of factors associated with failure of antibiotics to cure cows. The probability of curing an infected quarter decreased when SCC increased, when another quarter was infected in the same cow, when the infection was in a hind quarter or when the percentage of samples that was positive for $S$. aureus was higher before drying off. Osteras et al. [2] identified a number of determinants of success or failure for the elimination of major pathogens (mainly $S$. aureus and Streptococcus dysgalactiae) in a study including 686 cows from 288 different herds in Norway. They found better elimination of these pathogens to be associated with a lower mean value of the last three composite SCC before dry cow therapy and that cows with a major pathogen in the right hind quarter at dry off or at least 1 case of acute clinical mastitis during the previous lactation were more likely to have a major pathogen in the next lactation (odds ratio $=4.1$ and 3.6, respectively). It cannot be assumed that the factors which affect the cure of IMI due to treatment have the same impact upon the ability of a cow or quarter to self-cure.

\section{Acknowledgment}

Authors thank the many dairy herd owners without whose help this study would not have been possible, and Alan Zimmerman for statistical advice.

\section{References}

1. Sol J, Sampimon OC, Snoep JJ, Schukken YH (1994) Factors associated with bacteriological cure after dry cow treatment of subclinical Staphylococcal mastitis with antibiotics. J Dairy Sci 77: 75-79. [Crossref]

2. Osterås O, Edge VL, Martin SW (1999) Determinants of success or failure in the elimination of major mastitis pathogens in selective dry cow therapy. J Dairy Sci 82: 1221-1231. [Crossref]

3. Schukken YH, González RN, Tikofsky LL, Schulte HF, Santisteban CG, et al. (2009) CNS mastitis: nothing to worry about? Vet Microbiol 134: 9-14. [Crossref]

4. Tenhagen BA, Hansen I, Reinecke A, Heuwieser W (2009) Prevalence of pathogen in milk samples of dairy cows with clinical mastitis and in heifers at first parturition. $J$ Dairy Res 76: 179-187. [Crossref]

5. Jones GM, Pearson RE, Clabaugh GA, Heald CW (1984) Relationships between somatic cell counts and milk production. J Dairy Sci 67: 1823-1831. [Crossref]

6. Bar D, Tauer LW, Bennett G, Gonzalez RN, Hertl JA, et al. (2008) The Cost of Generic Clinical Mastitis in Dairy Cows as Estimated by Using Dynamic Programming. J Dairy Sci 91: 2205-2214. [Crossref]

7. Hagnestam C, Emanuelson U, Berglund B (2007) Yield Losses Associated with Clinical Mastitis Occurring in Different Weeks of Lactation. J Dairy Sci 90: 22602270. [Crossref]

8. Hagnestam-Nielsen C, Ostergaard S (2009) Economic impact of clincial mastitis in a dairy herd assessed by stochastic simulation using different methods to model yield losses. Animal 3: 315-328. [Crossref]

9. Hagnestam-Nielsen C, Emanuelson U, Berglund B, Strandberg E (2009) Relationship between somatic cell count and milk yield in different stages of lactation. $J$ Dairy Sci 92: 3124-3133. [Crossref]

10. Halasa T, Huijps K, Østerås O, Hogeveen H (2007) Economic effects of bovine mastitis and mastitis management: a review. Vet $Q 29: 18-31$. [Crossref]

11. Huijps K, Lam TJ, Hogeveen H (2008) Costs of mastitis: facts and perception. J Dairy Res 75: 113-120. [Crossref]

12. Hultgren J, Svensson C (2009) Lifetime risk and cost of clinical mastitis in dairy cows in relation to heifer rearing conditions in southwest Sweden. J Dairy Sci 92: 3274-3280. [Crossref]

13. Kossaibati MA, Esslemont RJ (1997) The costs of production diseases in dairy herds in England. Vet $J$ 154: 41-51. [Crossref]

14. Ostergaard S, Gröhn YT (1999) Effects of diseases on test day milk yield and body weight of dairy cows from Danish research herds. J Dairy Sci 82: 1188-1201. [Crossref]

15. Seegers H, Fourichon C, Beaudeau F (2003) Production effects related to mastitis and 
mastitis economics in dairy cattle herds. Vet Res 34: 475-491. [Crossref]

16. Ott SL (1999) Costs of Herd-Level Production Losses Associated with Subclinica Mastitis in U.S. Dairy Cows. 1999 National Mastitis Council 38th Annual Meetings Proceedings, (p. 152).

17. Heikkilä AM, Nousiainen JI, Pyörälä S (2012) Costs of clinical mastitis with special reference to premature culling. J Dairy Sci 95: 139-150. [Crossref]

18. Holland JK, Hadrich JC, Wolf CA, Lombar K (2015) Economics of Measuring Costs Due to Mastitis-Related Milk Loss. AAEA\& WAEA Joint Annual Meeting San Francisco, California.

19. Wolfinger R, O’Connell M (1993) Generalized linear mixed models: a pseudolikelihood approach. Journal of Statistical Computation and Simulation 48: 233-243.

20. CVMP (1999) Veterinary medicinal products administered via the teat duct to cows at drying off for the treatment of subclinical mastitis and prevention of new infections. 137-140. Guidelines for the testing of veterinary medicinal products Volume VII. European Commission. Luxembourg.

21. CVM (1995) Guidance document. Center for Veterinary Medicine. Food and Drug Administration. Washington, DC.

22. Thorburn A (1990) General principles for the design of clinical trials with special reference to mastitis therapy. IDF Bulletin 247: $39-48$
23. Whitaker DA, Kelly JM, Smith S (2000) Disposal and disease rates in 340 British dairy herds. Vet Rec 146: 363-367. [Crossref]

24. Wilson DJ, Gonzalez RN, Sears PM (1995) Segregation or Use of Separate Milking Units for Cows Infected with Staphylococcus aureus: Effects on Prevalence of Infection and Bulk Tank Somatic Cell Count. J Dairy Sci 78: 2083-2085. [Crossref]

25. Zecconi A, Piccinini R (1999) Culturing and identifying Staph. aureus in dairies: how many Staph. aureus do we have? Proc 38th Annual Meeting of the National Mastitis Council. Arlington 48-57.

26. Nickerson SC, Owens WE, Boddie RL (1995) Mastitis in dairy heifers: initial studies on prevalence and control. J Dairy Sci 78: 1607-1618. [Crossref]

27. Schukken YH, Vanvliet J, Vandegeer D, Grommers FJ (1993) A randomized blind trial on dry cow antibiotic infusion in a low somatic cell count herd. J Dairy Sci 76: 2925 2930. [Crossref]

28. Erskine RJ (1992) Mastitis control in dairy herds with high prevalence of subclinical mastitis. Compendium of Continuing Education 14: 969-1007.

29. Rivas AL, Gonzalez RN, Wiedmann M, Bruce JL, Cole EM, et al. (1997) Diversity of Streptococcus agalactiae and Staphylococcus aureus ribotypes recovered from New York dairy herds. AJVR. 58: 482-486.

30. Reeve-Johnson L (2003) Use of Random Amplified Polymorphic DNA analysis to verify antimicrobial efficacy when treating Staph. aureus mastitis in cows. Vet Rec $153: 788$.

Copyright: (C2017 Reeve-Johnson L. This is an open-access article distributed under the terms of the Creative Commons Attribution License, which permits unrestricted use, distribution, and reproduction in any medium, provided the original author and source are credited. 